\title{
The assessment of disability related to vision performance-based measure in diabetic retinopathy.
}

\author{
Kevin J. Warrian \\ Wills Eye Institute \\ Luciano L. Lorenzana \\ Wills Eye Institute \\ Dara Lankaranian \\ Wills Eye Institute \\ Jyoti Dugar \\ Wills Eye Institute \\ Sheryl S. Wizov \\ Wills Eye Institute \\ Follow this and additional works at: https://jdc.jefferson.edu/willsfp \\ Part of the Ophthalmology Commons

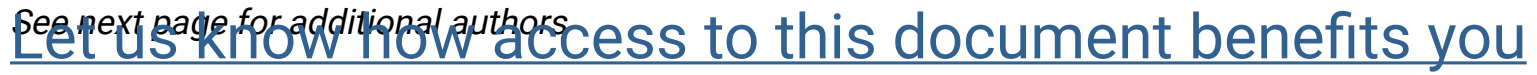

\section{Recommended Citation}

Warrian, Kevin J.; Lorenzana, Luciano L.; Lankaranian, Dara; Dugar, Jyoti; Wizov, Sheryl S.; and Spaeth, George L., "The assessment of disability related to vision performance-based measure in diabetic retinopathy." (2010). Wills Eye Hospital Papers. Paper 4.

https://jdc.jefferson.edu/willsfp/4

This Article is brought to you for free and open access by the Jefferson Digital Commons. The Jefferson Digital Commons is a service of Thomas Jefferson University's Center for Teaching and Learning (CTL). The Commons is a showcase for Jefferson books and journals, peer-reviewed scholarly publications, unique historical collections from the University archives, and teaching tools. The Jefferson Digital Commons allows researchers and interested readers anywhere in the world to learn about and keep up to date with Jefferson scholarship. This article has been accepted for inclusion in Wills Eye Hospital Papers by an authorized administrator of the Jefferson Digital Commons. For more information, please contact: JeffersonDigitalCommons@jefferson.edu. 


\section{Authors}

Kevin J. Warrian, Luciano L. Lorenzana, Dara Lankaranian, Jyoti Dugar, Sheryl S. Wizov, and George L. Spaeth 


\title{
As submitted to:
}

\section{American journal of ophthalmology}

\author{
And later published as:
}

\section{The Assessment of Disability Related to Vision Performance- Based Measure in Diabetic Retinopathy}

\section{Volume 149, Issue 5, May 2010, Pages 852-860.e1 doi:10.1016/j.ajo.2009.12.028}

\author{
Kevin J. Warrian, M.D., M.A. ${ }^{1}$ \\ Luciano L. Lorenzana, M.D. ${ }^{1}$ \\ Dara Lankaranian, M.D. ${ }^{1}$ \\ Jyoti Dugar, M.D. ${ }^{1}$ \\ Sheryl S. Wizov, C.O.A. ${ }^{1}$ \\ George L. Spaeth, M.D. ${ }^{2}$

\footnotetext{
${ }^{1}$ Glaucoma Research Center, William and Anna Goldberg Glaucoma Service, Wills Eye Institute, Philadelphia, PA

${ }^{2}$ Louis J. Esposito Research Professor, Department of Ophthalmology, Jefferson Medical College/ William and Anna Goldberg Glaucoma Service, Wills Eye Institute, Philadelphia, PA

Corresponding Author and Reprint Requests to:

Kevin J. Warrian kevinjwarrian@gmail.com
}

None of the authors have a financial interest in the submitted publication.

This study was conducted at Wills Eye Institute, Philadelphia, PA. 
Purpose: To validate a third generation performance based measure of visual function titled the "Assessment of Disability Related to Vision" (ADREV) in a study population of patients with diabetic retinopathy.

Design: Prospective, cross-sectional study.

Methods: Patients with non-proliferative or proliferative diabetic retinopathy, free from ocular comorbidity were recruited from a single institute and completed the ADREV, the 25-Item National Eye Institute's Visual Functioning Questionnaire (VFQ), and a clinical ophthalmic examination. Correlation, regression and bootstrap analysis were conducted to determine the relationship between ADREV scoring and each of the study's clinical and self-report measures of visual ability, while controlling for potential confounders. Results: 91 patients with diabetic retinopathy completed the study and analysis showed that the ADREV total and subscale scores shared a stronger relationship with the clinical measures of visual function than did the VFQ total and subscale scores. Regression analysis revealed that binocular visual acuity, contrast sensitivity and better eye visual field were the best predictors of ADREV performance.

Conclusions: The ADREV performance measure is a valid instrument for the assessment of disability related to vision in patients with diabetic retinopathy. Furthermore, the assessments provided by ADREV were more related to traditional clinical indicators of visual impairment than were the results of the selfreport measure, specifically, the VFQ-25. 


\section{Introduction}

Assessing visual health is a fundamental goal of ophthalmic practice. How one defines visual health has important implications for how it is measured and appraised. While the definition of health is subject to extensive debate, most individuals can agree that health involves the ability of an individual to perform common activities essential to modern life. Indeed, few would contest the idea that one lacks some measure of health if they are unable to perform essential activities of daily living such as walking, recognizing friendly faces and finding dropped items. While these ideas seem self-evident, the assessment of one's ability to perform activities of daily living is rarely used to assess visual health. Traditional assessments of vision typically involve four types of information: 1) symptoms acquired through a medical history; 2) signs obtained through physical examination; 3) laboratory data; and 4) anatomic data acquired through various imaging modalities. Importantly, the advancement of modern biotechnology has provided novel methods of technology-intensive evaluations in the form of more sensitive imaging and laboratory assessments of visual health, such as confocal scanning laser ophthalmoscopy, optical coherence tomography and genetic analysis. However, it is evident that the results of these high-technology assessments are often unrelated to one's ability to carry out daily activities. The disjunction between the current trend of high-technology assessment and the ability to function at a practical level is representative of the often encountered discrepancy between what is important to clinicians and what is important to patients.

Over the last decade the discipline of visual health sciences has seen the growing use of standardized medical histories in the form of quality of life (QoL) questionnaires to evaluate the health of the visual system. This trend can be viewed, at least in part, as a means with which to address the discordance between high-technology disease assessment and its associated lack of focus on what is practically important to patients. While the growing use of vision-specific QoL surveys has provided important information about the impact of visual disease from a patient's perspective, this modality of evaluation comes with its own range of limitations. Health-related QoL surveys, including vision-specific questionnaires, are influenced by a very broad range of factors including patient personality, individual

preferences, personal biases, mental health, desire to mislead and desire to please. ${ }^{1-6}$ In an effort to 
develop new methods of assessing the visual health of patients, several investigators have developed and tested standardized protocols that evaluate the ability of individuals to perform visually-intensive daily activities. Although the content of these different investigative techniques tend to vary in the specific activities tested, they all have a common focus on detecting changes in very basic and practical visual abilities required to perform daily activities. The results of these studies have demonstrated that performance-based measures (PBMs) of visual function are valid and reliable measures of visual health. ${ }^{7-}$

${ }^{11}$ In the same tradition of research, the investigation presented here is intended to validate a thirdgeneration PBM of visual function titled the "Assessment of Disability Related to Vision" (ADREV) in a population of individuals with diabetic retinopathy.

\section{Methods}

Study participants were selected chronologically from individuals receiving care within the general ophthalmology clinics and private practices of retinal-vitreous specialists at Wills Eye Institute. Inclusion/ exclusion criteria included a diagnosis of either non-proliferative or proliferative diabetic retinopathy (DR), written and verbal English proficiency, no visually significant ocular comorbidity and no active visual rehabilitation treatments at the time of study participation. Cataract assessment was made using the Lens Opacities Classification System II (LOCS II) with exclusion of patients with a 2+ cataract in any category. ${ }^{12}$ Study participants were not to have had retinal photocoagulation treatments within one month of study participation. Individuals with medical comorbidities that resulted in significant neurological or other systemic manifestations that would have prevented them from completing the study's protocol were also excluded. Patients were selected to reflect a broad range of visual impairment based on better eye visual acuity and were identified using a process that included a medical chart review and brief interview. All prospective patients were fully informed regarding the details of the study and those who agreed to participate completed an informed consent process which was approved by the Wills Eye Institute Institutional Review Board (IRB) and in compliance with the Declaration of Helsinki. Study participants completed a new third-generation PBM titled the Assessment of Disability Related to Vision (ADREV). Patients were also asked to complete the 25-Item National Eye Institute's Visual Functioning Questionnaire (VFQ). All study participants received a standard ophthalmic clinical examination that 
included monocular and binocular visual acuity assessment using the Early Treatment Diabetic Retinopathy Study Lighthouse Chart $2^{\text {nd }}$ edition, Pelli-Robson binocular contrast sensitivity testing, monocular 24-2 Humphrey visual fields (HVF) in each eye and a slit-lamp examination including a clinical retinal examination in both eyes. Visual acuity measurements were converted to logMAR equivalents using the methods employed by The Ischemic Optic Neuropathy Decompression Trial Research Group. ${ }^{13}$ Finally, demographic data was collected using a standard form and included age, gender, ethnicity and medical comorbidities.

The ADREV instrument is based on a prior investigation involving an alternative PBM titled the Assessment of Function Related to Vision (AFREV). ${ }^{14}$ The AFREV instrument validated five tests of performance of visually-intensive tasks based on Item Response Theory in the form of Rasch analysis and significant relationships with both traditional clinical measures of opthalmic status, as well as selfreported vision-specific QoL measured by the National Eye Institute's Visual Functioning Questionnaire (VFQ). The instrument employed within the context of this investigation, titled the ADREV, was developed based on the findings of the AFREV experiment and the details of its design have been documented elsewhere. ${ }^{15}$ The ADREV is comprised of 9 tests including: 1) Reading in Reduced Illumination, 2) Facial Expression Recognition, 3) Computerized Motion Detection, 4) Recognizing Street Signs, 5) Locating Objects, 6) Ambulation, 7) Placing a Peg into Different Sized Holes, 8) Telephone Simulation, and 9) Matching Socks. A description of each test item is presented in Figure I: ADREV Test Description. Each test of performance is graded from 0 - 7 on an interval scale determined through Rasch analysis; where 0 represents the inability to perform the test and 7 indicates a perfect score. In addition to the subscale evaluations, the nine tests are summed to produce an ADREV total score ranging from $0-63$. The subscales can be employed and interpreted independently from the ADREV total score. Average test administration time, including patient instruction is approximately 30 minutes. The ADREV has been previously validated in a study population involving patients with age-related macular degeneration through comparison with standard clinical measures of visual function and self-reported QoL. ${ }^{16}$ 
The VFQ was selected as the study's primary QoL measurement as it is accepted as a reliable and valid means of studying the self-perceived impact of visual impairment upon vision-specific QoL. ${ }^{17-19}$ The VFQ is a generic vision-specific instrument that was designed to study a wide variety of ocular diseases and a number of studies have used the VFQ to study the self-reported QoL of patients with DR. ${ }^{18-22}$ The 25 -item VFQ is comprised of eleven vision-specific subscales that address the following domains: 1) general vision, 2) near vision, 3) distance vision, 4) ocular pain, 5) social functioning, 6) mental health, 7) role difficulties, 8) dependency, 9) driving, 10) color vision and 11) peripheral vision. Each subscale is scored from $0-100$, where 100 represents self-perceived perfect functioning and 0 represents the greatest level of difficulty in a given domain. The eleven subscales are also averaged to produce a VFQ total score ranging from $0-100$. The average test administration time for the VFQ is approximately 10 minutes.

Data analysis was conducted in several steps. First, all variables were plotted and reviewed for outliers that might represent data entry errors. Descriptive statistics were computed for demographic, past medical, clinical ophthalmic, QoL and PBM measures. Independent $t$ tests were used to determine if any differences existed in average VFQ and ADREV total and subscale scoring based on dichotomous demographics. Analysis of variance (ANOVA) was conducted to identify statistically significant differences in mean VFQ and ADREV total and subscale scores with respect to categorical variables that lacked an inherent conceptual hierarchy. Spearman's rho was used to determine correlative relationships between the study's clinical variables and both the VFQ and ADREV total and subscale scores, as well as between the VFQ and ADREV total and subscale scores. Spearman's nonparametric statistic was chosen to standardize comparisons as selected portions of the data provided by the VFQ total and subscale scores do not meet the requirements of interval variables. ${ }^{23,}{ }^{24}$ Correlation coefficients $(r)$ were considered small if less than 0.3 , medium between 0.3 and 0.5 and large if greater than $0.5{ }^{25}$ In addition, a robust regression analysis using Huber's Method was used to determine the clinical measures that are most associated with each of the ADREV total and subscale scores, while controlling for age, gender, ethnicity and total number of medical comorbidities. ${ }^{24}$ This approach was chosen for several reasons. Robust regression is a valid statistical method for data that meet the criteria for analysis with ordinary least squares regression (OLS); however, it is also resistant to the effects of data outliers and can analyze non- 
normally distributed, categorical and binary data. ${ }^{26,}{ }^{27}$ All variables were entered into the regression equations simultaneously and no automated variable selection process was utilized. Prior to regression equation construction, a correlation matrix using Spearman's rho was completed using all of the study's independent and control variables to identify and exclude collinear relationships from the regression analysis based on correlations of $r>l=0.9 .^{28}$ Scatterplots were constructed between the measures of clinical ophthalmic status and the ADREV total and subscale scores in order to detect any non-linear relationships. Independent and control variables were entered into the regression equation irrespective of the presence or absence of significant bivariate relationships with ADREV total or subscale scoring. In keeping with accepted statistical practice, the number of independent and control variables included in each regression equation was equal to or less than $1 / 10$ the total number of cases in our sample population. ${ }^{29}$ Residual statistics for each regression equation were plotted to identify highly significant outliers that might have compromised the explanatory power of each regression equation. A supplementary bootstrap analysis of 1,000 random resampled data sets was conducted to test the external validity of the relationships identified during initial regression modeling. ${ }^{30-32}$ Where appropriate, all statistical tests were run in a two-tailed fashion and corrections for multiple comparisons were made using the Bonferroni method. ${ }^{33}$ A power analysis based on the effect sizes noted in the AFREV experiment indicated that a sample population of 90 individuals would be adequate to detect an $r=0.3$ with $80 \%$ power and $a=0.05 .^{14,34}$

\section{Results}

Our final sample population consisted of $91 \mathrm{DR}$ patients and the results of our statistical analysis are presented in Appendix II. The average age of participants was 61 with a standard deviation (SD) of $+/-11$ years. The study population had slightly unequal representation based on gender with $35 \%(n=32)$ being male. There were nearly equal numbers of individuals from European $(n=47)$ and African extraction $(n=$ 40 ), with the remainder of the group being comprised of three Hispanic individuals and one person of Asian descent. The average number of medical comorbidities was 2.7 (SD +/- 1.6). The five most common comorbidities included hypertension (59.3\%), hypothyroidism (20.9\%), hypercholesteremia (6.6\%), osteoarthritis (6.6\%) and hyperthyroidism (6.6\%). The population consisted of 178 eyes 
diagnosed with DR with seventy three eyes $(41 \%)$ having a diagnosis of non-proliferative DR, while the remaining one hundred and five eyes (59\%) had a diagnosis of proliferative DR. Descriptive statistics of the study populations' clinical ophthalmic assessments, ADREV and VFQ total and subscale scores are presented in Table I. The study group included a wide range of better eye visual acuity measurements ranging from 20/20 through to NLP. Worse eye visual field MD values were equally varied and included individuals with full visual fields through to end stage peripheral visual loss. ADREV total and subscale scores represented the full range of possible scoring. VFQ total and subscale scores were similar to the results published by Tranos et al. (2004), but somewhat lower than those published by Klien et al (2001). ${ }^{20,}{ }^{21}$ A comparison of mean ADREV total and subscale scores with respect to gender revealed only one significant difference with females scoring slightly higher (5.85) than males (5.19) on the Ambulation test. There were no significant relationships between patient performance on the ADREV total and subscale scores based on age, number of comorbid medical conditions or self-reported ethnicity.

Bivariate analysis between the study's' clinical variables and the ADREV total and subscale measures demonstrated that 53 of the total $60(88 \%)$ comparisons were significant to $p<0.05$ (Table II). After adjustment for multiple comparisons, 49 of the 60 comparisons $(82 \%)$ were statistically significant to $p<$ 0.0007 (Table II). After correction for multiple comparisons, all but one of the ADREV's scales were correlated with one or more of the clinical measures of visual function with only the Ambulation test having no significant bivariate correlation to the clinical measures. The four strongest relationships included: 1) binocular visual acuity and ADREV total score ( $r=-.780)$; 2) binocular visual acuity and Recognizing Street Signs $(r=-.772)$; 3) better eye visual acuity and Recognizing Street Signs $(r=-.731)$; and 4) better eye visual acuity and ADREV total score $(r=-.725)$. The mean absolute correlation magnitude for all significant relationships between the ADREV, its subscales and all clinical measures was r .515 (SD +/- .108).

In contrast, the correlative analysis between the VFQ total and subscale scores with the study's clinical measures of visual function revealed 63 of the 72 comparisons $(88 \%)$ were significant to $p<0.05$. After adjustment for correction for multiple comparisons, fifty two of the seventy two comparisons (72\%) were 
statistically significant to $p<0.0006$. The strongest four relationships were: 1 ) better eye visual acuity and Mental Health ( $r=-.550)$; 2) worse eye visual acuity and VFQ total score $(r=-.542)$; 3) worse eye MD and VFQ total score $(r=.538)$; and 4$)$ better eye visual acuity and VFQ total score $(r=-.533)$. The mean absolute correlation magnitude between the VFQ, its subscales and all of the clinical measures was $r=$ .438 (SD +/- .054). A one sample $t$ test between the mean absolute correlation magnitude for all significant correlative relationships between the ADREV-clinical measures analysis and the VFQ-clinical measures analysis revealed that the higher mean correlations between the ADREV and the clinical measures was statistically significant $(p<0.001)$.

Table IV summarizes a direct comparison between the ADREV and VFQ total and subscale scores. Initial analysis revealed that 81 of the 120 comparisons $(68 \%)$ were significant to $p<0.05$. After correction for multiple comparisons, 42 relationships (35\%) were significant to $p<0.0004$. The four strongest correlations were between: 1) Motion Detection and VFQ total score ( $r=.523)$; 2) Motion Detection and Near Activities ( $r=.520)$; 3) Facial Expression Recognition and VFQ total score $(r=.514)$; and 4) Facial Expression Recognition and Mental Health $(r=.501)$. The mean absolute correlation magnitude between the ADREV and VFQ total and subscale scores was $r=.431(\mathrm{SD}+/-.048)$.

The results of the robust regression analysis between the ADREV total and subscale scores and the study's clinical variables are presented in Table V. Prior to building each equation, a correlation matrix of the study's clinical variables indicated that binocular visual acuity and better eye visual acuity had a correlation coefficient equal to 0.9 . Based on this exceptionally strong relationship, as well as the related nature of the two measures, this finding was interpreted to mean that the two assessments were measuring the same phenomenon. In cases where both binocular visual acuity and better eye visual acuity were correlated with the ADREV total or subscale scores, the measure with the stronger relationship was included in the regression equation. Scatterplot analysis did not reveal any non-linear relationships. No data was removed following residual statistical analysis. For each of the ADREV's total and subscale scores, the statistically significant independent variables predictive of patient performance are presented in Table $\mathrm{V}$ in order of beta weight magnitude. Independent variables that remained 
significant within the $95 \% \mathrm{Cl}$ following bootstrap analysis are also presented in Table $\mathrm{V}$. The results of the regression analysis indicated that binocular visual acuity, binocular contrast sensitivity and better eye visual field are all significantly related to the performance of DR patients on the ADREV, irrespective of age, gender, ethnicity or total number of medical comorbidities.

\section{Discussion}

This study had several limitations. To begin, all individuals were recruited from a single tertiary ophthalmic hospital and it may not be possible to validly generalize our findings to all individuals. Study participants completed approximately two hours of testing as part of the study protocol and fatigue may have influenced the results of our testing. Indicators of clinical depression were not collected and individuals suffering from clinical depression may have influenced the reported scores on the VFQ. ${ }^{3,35}$ The study population size was also limited to ninety one individuals and it is possible that additional, weaker relationships were not detected. Our inclusion/ exclusion criteria removed all individuals with ocular comorbidity, as well as any serious musculoskeletal or neurological impairment that might have influenced their testing results and this may limit the applicability of our results to all patient subpopulations. Furthermore, other clinical measures of visual function such as stereopsis, glare testing and color vision were not completed by the study population and there may be additional associations between these measures and the ADREV that were not measured by this investigation. It should also be acknowledged that while the activities chosen for the ADREV are commonly encountered in daily living, not all individuals will perform these activities or value them to the same extent. Others have elected to have patients weigh the importance of each activity used in performance testing and this approach could be employed to improve future versions of the ADREV. ${ }^{36}$

Despite these potential limitations, the results of our investigation support the validity of the ADREV performance measure for assessing visual ability in patients with diabetic retinopathy. Strong to moderate bivariate associations existed between multiple measures of clinical ophthalmic status, as well as selfreported vision-specific QoL. Moreover, in comparison to vision-specific QoL measured by the VFQ, the ADREV PBM shared a significantly stronger relationship to all of the traditional measures of clinical 
assessment. Regression analysis demonstrated that each of the clinical measures of visual function including visual acuity, contrast sensitivity and visual field remained highly associated with ADREV total and subscale scoring, after controlling for age, gender, ethnicity and medical comorbidity. Importantly, however, while the relationships noted between traditional measures of ophthalmic status and the ADREV were large in magnitude, they were not large enough to validly infer that traditional ophthalmic measures can be used as surrogates for the evaluations provided by the ADREV. Though highly related, the moderate to strong relationships noted in this study between traditional clinical measures of visual function and ADREV performance provide support to the notion that measurements of actual patient performance provide qualitatively different information than surrogate measures of functional performance such as visual acuity, contrast sensitivity or visual field measurements.

All of the relationships fit well with our current understanding of the types of visual abilities affected by patients with DR. The role of better eye visual field in the ability to correctly match socks from a presented selection likely relates to the ability to simultaneously survey several different items in order to correctly match similar items. Individuals with "tunnel vision" due to a constricted visual field would be less able to simultaneously compare the visual qualities of multiple items that need to be viewed across a larger expanse of visual field. The importance of central visual acuity in reading, facial recognition, reading street signs and dialing a telephone is readily apparent. Similarly, the relationship found between better eye visual field and motion detection is well supported by prior research. ${ }^{37}$ The role of contrast sensitivity appeared important when performing a number of different activities. Contrast sensitivity proved to be related to the ability to discern significant detail, including facial expression recognition and placing a peg into a small hole; yet also had an important association with the ability to locate objects in a room. These findings are consistent with the types of visual loss that patients with DR often experience related to not only the natural history of the disease, but also to the reduction in peripheral vision associated with retinal photocoagulation used to preserve central visual function. These findings emphasize the multi-faceted nature of the visual abilities required to function in day to day living and the many different visual challenges faced by patients with DR. 
In comparison to the previous investigation involving the ADREV and patients with AMD we noted similar absolute mean correlative bivariate relationships between the ADREV total and subscale scores and clinic measures of visual function (DR $r=0.515$, AMD $r=0.569) .{ }^{16}$ A number of similarities were also noted between the strongest bivariate relationships when comparing the clinical measures of visual impairment and ADREV performance in both the DR and AMD populations. Specifically, binocular visual acuity and better eye visual acuity were most related to ADREV scoring in both the DR and AMD groups. Comparison of the results of regression analysis between the AMD and DR populations showed similar associations relating binocular visual acuity and contrast sensitivity to ADREV total and subscale performance. However, unlike the AMD population, the DR population showed a significant relationship between ADREV total and subscale performance and better eye visual field. The latter relationship likely relates to DR patients who have peripheral visual field loss following pan-retinal photocoagulation for proliferative disease.

The value of performance measures lies in the clear content validity of the data they provide. Patients are deeply aware of how their illness affects their ability to perform activities that matter to them. In this regard, the information provided by performance-based assessment is unique. Performance measures provide a standardized and valid means of assessing visual disease, while simultaneously providing an evaluation that carries far more importance to patients than traditional clinical, laboratory or imaging assessments. From this perspective, PBMs are able to bridge the gap between the goals of self-reported evaluations aimed at ascertaining the importance of disease impact to patients, and the standardized character of traditional measures of visual function taken in an office setting. It is hoped that PBMs will serve as means with which to acquire the best of both of these assessments, while avoiding many of the confounding factors of self-report, as well as the irrelevant quality of many of the traditional measures of visual function. For these reasons future investigators should consider utilizing PBMs of visual ability in vision research and ophthalmic practice. 


\section{Acknowledgements:}

a. Financial /Support: Provided by Pfizer, The Perelman Fund through the Wills Eye Institute of Jefferson Medical College, The Pearle Vision Foundation and The Glaucoma Service Foundation to Prevent Blindness.

b. Financial Disclosures: Dr. G. L. Spaeth has current grant support from Pfizer \& Allergan.

C. Design of study (L.L.L., D.L., S.S.W., G.L.S.), Analysis and interpretation (K.J.W., D.L., G.L.S.), Article writing (K.J.W., G.L.S.), Critical revision of article (K.J.W., D.L., G.L.S.), Final approval of article (K.J.W., D.L., G.L.S.), Data collection (L.L.L., D.L., S.S.W.), provision of materials, patients, or resources (L.L.L., D.L., S.S.W., G.L.S.), Statistical expertise (K.J.W., D.L.), Obtaining funding (L.L.L., G.L.S.), Literature search (K.J.W., L.L.L., D.L., G.L.S.), Administrative, technical or logistic support (L.L.L., D.L., S.S.W.)

d. All patients were fully informed regarding the details of the study and those who agreed to participate completed an informed consent process which was approved by the Wills Eye Institute Institutional Review Board (IRB) and in compliance with the Declaration of Helsinki. 


\begin{tabular}{|c|c|c|c|c|c|c|}
\hline Clinical Variables & Mean & Median & SD & Skew & Range & $\mathrm{n}$ \\
\hline Binocular Visual Acuity & .358 & .300 & 1.66 & .279 & $0-1.9$ & 91 \\
\hline Better Eye Visual Acuity & .406 & .340 & .350 & 2.65 & $0-1.9$ & 91 \\
\hline Worse Eye Visual Acuity & .829 & .620 & .682 & 1.46 & $0-2.8$ & 91 \\
\hline Contrast Sensitivity & 1.25 & 1.25 & .272 & -1.28 & $.15-1.65$ & 91 \\
\hline Mean Deviation Better Eye & -9.81 & -7.78 & 7.16 & -1.03 & $-28.96--.06$ & 91 \\
\hline Mean Deviation Worse Eye & -13.92 & -10.38 & -10.38 & -.893 & $-40--1.0$ & 91 \\
\hline $\begin{array}{l}\text { Assessment of Disability Related to } \\
\text { Vision Total Score }\end{array}$ & 44.1 & 45.8 & 9.96 & -.89 & $15-61$ & 91 \\
\hline Reading in Reduced Illumination & 5.0 & 5.0 & 1.63 & -.62 & $0-7$ & 91 \\
\hline Facial Expression Recognition & 4.7 & 5.0 & 1.81 & -.81 & $0-7$ & 91 \\
\hline Motion Detection & 5.3 & 5.0 & 1.14 & -.01 & $2-7$ & 91 \\
\hline Recognizing Street Signs & 3.8 & 4.0 & 1.58 & -.70 & $0-6$ & 91 \\
\hline Locating Objects & 5.0 & 5.5 & 1.28 & -.73 & $2-7$ & 91 \\
\hline Ambulation & 5.6 & 5.7 & .97 & -1.45 & $2-7$ & 91 \\
\hline Placing Peg into Holes & 4.6 & 5.0 & 1.61 & -.47 & $0-7$ & 91 \\
\hline Telephone Simulation & 5.1 & 5.0 & 1.83 & -.93 & $0-7$ & 91 \\
\hline Matching Socks & 5.0 & 6.0 & 2.25 & -.80 & $0-7$ & 91 \\
\hline $\begin{array}{l}\text { Visual Functioning Questionnaire Total } \\
\text { Score }\end{array}$ & 70.0 & 72.5 & 18.78 & -.66 & $20-98$ & 91 \\
\hline General Vision & 61.7 & 60.0 & 18.77 & -.43 & $20-100$ & 91 \\
\hline Ocular Pain & 78.3 & 87.5 & 20.82 & -.71 & $13-100$ & 91 \\
\hline Near Activities & 61.5 & 58.3 & 23.23 & -.03 & $8-100$ & 91 \\
\hline Distance Activities & 67.5 & 66.7 & 22.8 & -.43 & $17-100$ & 91 \\
\hline Social Functioning & 81.2 & 87.5 & 22.3 & -1.25 & $13-100$ & 91 \\
\hline Mental Health & 64.1 & 68.8 & 27.0 & -.76 & $0-100$ & 91 \\
\hline Role Difficulties & 59.2 & 62.5 & 32.0 & -.24 & $0-100$ & 90 \\
\hline Dependency & 78.0 & 75.0 & 27.1 & -1.24 & $0-100$ & 91 \\
\hline Driving & 68.9 & 75.0 & 27.1 & -1.24 & $0-100$ & 54 \\
\hline Color Vision & 82.7 & 100 & 22.6 & -1.12 & $25-100$ & 91 \\
\hline Peripheral Vision & 69.2 & 75.0 & 26.9 & -.24 & $25-100$ & 91 \\
\hline
\end{tabular}




\begin{tabular}{|c|c|c|c|c|c|c|}
\hline & $\begin{array}{c}\text { Binocular } \\
\text { Visual Acuity } \\
\text { (n) }\end{array}$ & $\begin{array}{c}\text { Better Eye } \\
\text { Visual Acuity } \\
\text { (n) }\end{array}$ & $\begin{array}{c}\text { Worse Eye } \\
\text { Visual Acuity } \\
\text { (n) }\end{array}$ & $\begin{array}{c}\text { Contrast } \\
\text { Sensitivity } \\
\text { (n) }\end{array}$ & $\begin{array}{c}\text { Better Eye } \\
\text { Mean Deviation } \\
(\mathrm{n})\end{array}$ & $\begin{array}{c}\text { Worse Eye } \\
\text { Mean Deviation } \\
(\mathrm{n})\end{array}$ \\
\hline $\begin{array}{l}\text { Assessment of } \\
\text { Disability } \\
\text { Related to } \\
\text { Vision } \\
\end{array}$ & $\begin{array}{c}-.780^{*} \\
(91)\end{array}$ & $\begin{array}{c}.725^{*} \\
(91)\end{array}$ & $\begin{array}{c}-.566^{*} \\
(91)\end{array}$ & $\begin{array}{l}.610^{*} \\
(91)\end{array}$ & $\begin{array}{l}.571^{*} \\
(91)\end{array}$ & $\begin{array}{l}.564^{*} \\
(91)\end{array}$ \\
\hline $\begin{array}{l}\text { Reading in } \\
\text { Reduced } \\
\text { Illumination }\end{array}$ & $\begin{array}{c}-.418^{*} \\
(91)\end{array}$ & $\begin{array}{c}-.337 \\
(91)\end{array}$ & $\begin{array}{c}-.280 \\
(91)\end{array}$ & $\begin{array}{l}.143 \\
(91)\end{array}$ & $\begin{array}{l}.190 \\
(91)\end{array}$ & $\begin{array}{l}.169 \\
(91)\end{array}$ \\
\hline $\begin{array}{l}\text { Facial } \\
\text { Expression } \\
\text { Recognition }\end{array}$ & $\begin{array}{c}-.667^{*} \\
(91)\end{array}$ & $\begin{array}{c}-.637^{*} \\
(91)\end{array}$ & $\begin{array}{c}-.491^{*} \\
(91)\end{array}$ & $\begin{array}{l}.549^{*} \\
(91)\end{array}$ & $\begin{array}{l}.417^{*} \\
(91)\end{array}$ & $\begin{array}{l}.487^{*} \\
(91)\end{array}$ \\
\hline $\begin{array}{l}\text { Motion } \\
\text { Detection }\end{array}$ & $\begin{array}{c}-.538^{*} \\
(91)\end{array}$ & $\begin{array}{c}-.519^{*} \\
(91)\end{array}$ & $\begin{array}{c}-.458^{*} \\
(91)\end{array}$ & $\begin{array}{l}.475^{*} \\
(91)\end{array}$ & $\begin{array}{l}.624^{*} \\
(91)\end{array}$ & $\begin{array}{l}.508^{*} \\
(91)\end{array}$ \\
\hline $\begin{array}{l}\text { Recognizing } \\
\text { Street Signs }\end{array}$ & $\begin{array}{c}-.772^{*} \\
(91)\end{array}$ & $\begin{array}{c}-.731^{*} \\
(91)\end{array}$ & $\begin{array}{c}-.404^{*} \\
(91)\end{array}$ & $\begin{array}{l}.603^{*} \\
(91)\end{array}$ & $\begin{array}{l}.559^{*} \\
(91)\end{array}$ & $\begin{array}{l}.436^{*} \\
(91)\end{array}$ \\
\hline $\begin{array}{l}\text { Locating } \\
\text { Objects }\end{array}$ & $\begin{array}{c}-.636^{*} \\
(91)\end{array}$ & $\begin{array}{c}-.605^{*} \\
(91)\end{array}$ & $\begin{array}{c}-.472^{*} \\
(91)\end{array}$ & $\begin{array}{l}.519^{*} \\
(91)\end{array}$ & $\begin{array}{l}.469^{*} \\
(91)\end{array}$ & $\begin{array}{l}.537^{*} \\
(91)\end{array}$ \\
\hline Ambulation & $\begin{array}{l}-.226 \\
(91)\end{array}$ & $\begin{array}{l}-.218 \\
(91)\end{array}$ & $\begin{array}{c}-.031 \\
(91)\end{array}$ & $\begin{array}{l}.153 \\
(91)\end{array}$ & $\begin{array}{l}.105 \\
(91)\end{array}$ & $\begin{array}{l}.137 \\
(91)\end{array}$ \\
\hline $\begin{array}{l}\text { Placing Peg in } \\
\text { Holes }\end{array}$ & $\begin{array}{c}-.397^{*} \\
(91)\end{array}$ & $\begin{array}{l}-.411^{*} \\
(91)\end{array}$ & $\begin{array}{c}-.408^{*} \\
(91)\end{array}$ & $\begin{array}{l}.441^{*} \\
(91)\end{array}$ & $\begin{array}{l}.363^{*} \\
(91)\end{array}$ & $\begin{array}{l}.418^{*} \\
(91)\end{array}$ \\
\hline $\begin{array}{l}\text { Telephone } \\
\text { Simulation }\end{array}$ & $\begin{array}{c}-.623^{*} \\
(91)\end{array}$ & $\begin{array}{c}-.560^{*} \\
(91)\end{array}$ & $\begin{array}{c}-.446^{*} \\
(91)\end{array}$ & $\begin{array}{l}.473^{*} \\
(91)\end{array}$ & $\begin{array}{l}.424^{*} \\
(91)\end{array}$ & $\begin{array}{l}.394^{*} \\
(91)\end{array}$ \\
\hline Matching Socks & $\begin{array}{c}-.491^{*} \\
(91)\end{array}$ & $\begin{array}{c}-.464^{*} \\
(91)\end{array}$ & $\begin{array}{c}-.373^{*} \\
(91)\end{array}$ & $\begin{array}{l}.395^{*} \\
(91)\end{array}$ & $\begin{array}{l}.452^{*} \\
(91)\end{array}$ & $\begin{array}{l}.371^{*} \\
(91)\end{array}$ \\
\hline \multicolumn{5}{|c|}{ Bonferroni method used for adjustments for multiple comparisons. } & ${ }^{*} \mathrm{p}<0.05$ & $p>0.05$ \\
\hline
\end{tabular}




\begin{tabular}{|c|c|c|c|c|c|c|}
\hline & $\begin{array}{c}\text { Binocular } \\
\text { Visual Acuity } \\
\text { (n) }\end{array}$ & $\begin{array}{c}\text { Better Eye } \\
\text { Visual Acuity } \\
\text { (n) }\end{array}$ & $\begin{array}{c}\text { Worse Eye } \\
\text { Visual Acuity } \\
\text { (n) }\end{array}$ & $\begin{array}{c}\text { Contrast } \\
\text { Sensitivity } \\
\text { (n) }\end{array}$ & $\begin{array}{c}\text { Better Eye } \\
\text { Mean Deviation } \\
(\mathrm{n})\end{array}$ & $\begin{array}{c}\text { Worse Eye } \\
\text { Mean Deviation } \\
(\mathrm{n})\end{array}$ \\
\hline $\begin{array}{l}\text { Visual } \\
\text { Functioning } \\
\text { Questionnaire }\end{array}$ & $\begin{array}{c}-.502^{*} \\
(91)\end{array}$ & $\begin{array}{c}-.533^{*} \\
(91)\end{array}$ & $\begin{array}{c}-.542^{*} \\
(91)\end{array}$ & $\begin{array}{l}.497^{*} \\
(91)\end{array}$ & $\begin{array}{l}.470^{*} \\
(91)\end{array}$ & $\begin{array}{l}.538^{*} \\
(91)\end{array}$ \\
\hline General Vision & $\begin{array}{c}-.456^{*} \\
(91) \\
\end{array}$ & $\begin{array}{c}-.512^{*} \\
(91) \\
\end{array}$ & $\begin{array}{c}-.396^{*} \\
(91) \\
\end{array}$ & $\begin{array}{l}.378^{*} \\
(91) \\
\end{array}$ & $\begin{array}{l}.317 \\
(91) \\
\end{array}$ & $\begin{array}{l}.437^{*} \\
(91)\end{array}$ \\
\hline Ocular pain & $\begin{array}{c}-.177 \\
(91) \\
\end{array}$ & $\begin{array}{c}-.102 \\
(91) \\
\end{array}$ & $\begin{array}{l}-.126 \\
(91) \\
\end{array}$ & $\begin{array}{l}.060 \\
(91) \\
\end{array}$ & $\begin{array}{c}-.005 \\
(91) \\
\end{array}$ & $\begin{array}{l}.053 \\
(91)\end{array}$ \\
\hline Near Activities & $\begin{array}{c}-.401^{*} \\
(91) \\
\end{array}$ & $\begin{array}{c}-.476^{*} \\
(91) \\
\end{array}$ & $\begin{array}{c}-.475^{*} \\
(91) \\
\end{array}$ & $\begin{array}{l}.400^{*} \\
(91) \\
\end{array}$ & $\begin{array}{l}.458^{\star} \\
(91) \\
\end{array}$ & $\begin{array}{l}.409^{*} \\
(91)\end{array}$ \\
\hline $\begin{array}{l}\text { Distance } \\
\text { Activities }\end{array}$ & $\begin{array}{c}-.390^{*} \\
(91)\end{array}$ & $\begin{array}{c}-.419^{*} \\
(91)\end{array}$ & $\begin{array}{c}-.390^{*} \\
(91)\end{array}$ & $\begin{array}{l}.388^{*} \\
(91)\end{array}$ & $\begin{array}{l}.335 \\
(91)\end{array}$ & $\begin{array}{l}.331 \\
(91)\end{array}$ \\
\hline $\begin{array}{l}\text { Social } \\
\text { Functioning }\end{array}$ & $\begin{array}{c}-.421^{*} \\
(91) \\
\end{array}$ & $\begin{array}{c}-.425^{*} \\
(91) \\
\end{array}$ & $\begin{array}{c}-.399^{*} \\
(91) \\
\end{array}$ & $\begin{array}{l}.377 \\
(91) \\
\end{array}$ & $\begin{array}{l}.377^{*} \\
(91) \\
\end{array}$ & $\begin{array}{l}.414^{*} \\
(91)\end{array}$ \\
\hline Mental Health & $\begin{array}{c}-.519^{*} \\
(91) \\
\end{array}$ & $\begin{array}{c}-.550^{*} \\
(91) \\
\end{array}$ & $\begin{array}{c}-.462^{*} \\
(91) \\
\end{array}$ & $\begin{array}{l}.399^{*} \\
(91) \\
\end{array}$ & $\begin{array}{l}.348 \\
(91) \\
\end{array}$ & $\begin{array}{l}.526^{*} \\
(91) \\
\end{array}$ \\
\hline Role Difficulties & $\begin{array}{c}-.418^{*} \\
(91)\end{array}$ & $\begin{array}{c}-.461^{*} \\
(91)\end{array}$ & $\begin{array}{c}-.476^{*} \\
(91)\end{array}$ & $\begin{array}{l}.392^{*} \\
(91)\end{array}$ & $\begin{array}{l}.389^{*} \\
(91)\end{array}$ & $\begin{array}{l}.390^{*} \\
(91)\end{array}$ \\
\hline Dependency & $\begin{array}{c}-.410^{*} \\
(91) \\
\end{array}$ & $\begin{array}{c}-.405^{*} \\
(91) \\
\end{array}$ & $\begin{array}{c}-.390^{*} \\
(91) \\
\end{array}$ & $\begin{array}{l}.238 \\
(91) \\
\end{array}$ & $\begin{array}{l}.314 \\
(91) \\
\end{array}$ & $\begin{array}{l}.403^{*} \\
(91)\end{array}$ \\
\hline Driving & $\begin{array}{l}-.208 \\
(91) \\
\end{array}$ & $\begin{array}{l}-.288 \\
(91) \\
\end{array}$ & $\begin{array}{l}-.184 \\
(91) \\
\end{array}$ & $\begin{array}{l}.240 \\
(91) \\
\end{array}$ & $\begin{array}{l}.362 \\
(91) \\
\end{array}$ & $\begin{array}{l}.342 \\
(91) \\
\end{array}$ \\
\hline Color Vision & $\begin{array}{c}-.372^{*} \\
(91)\end{array}$ & $\begin{array}{c}-.397^{*} \\
(91)\end{array}$ & $\begin{array}{l}-.323 \\
(91)\end{array}$ & $\begin{array}{l}.373^{*} \\
(91)\end{array}$ & $\begin{array}{l}.351 \\
(91) \\
\end{array}$ & $\begin{array}{l}.392^{*} \\
(91)\end{array}$ \\
\hline $\begin{array}{l}\text { Peripheral } \\
\text { Vision }\end{array}$ & $\begin{array}{c}-.311 \\
(91) \\
\end{array}$ & $\begin{array}{c}-.312 \\
(91) \\
\end{array}$ & $\begin{array}{c}-.515^{*} \\
(91) \\
\end{array}$ & $\begin{array}{l}.448^{*} \\
(91) \\
\end{array}$ & $\begin{array}{l}.430^{*} \\
(91) \\
\end{array}$ & $\begin{array}{l}.516^{*} \\
(91) \\
\end{array}$ \\
\hline \multicolumn{5}{|c|}{ Bonferroni method used for adjustments for multiple comparisons. } & ${ }^{*} p<0.05$ & $p>0.05$ \\
\hline
\end{tabular}




\begin{tabular}{|c|c|c|c|c|c|c|c|c|c|c|c|c|}
\hline & $\begin{array}{l}\mathrm{VFQ}^{\dagger} \\
\text { (n) }\end{array}$ & $\begin{array}{l}\mathrm{GV}^{\dagger} \\
(\mathrm{n})\end{array}$ & $\begin{array}{l}\mathrm{OP}^{\dagger} \\
(\mathrm{n})\end{array}$ & $\begin{array}{l}\mathrm{NA}^{\dagger} \\
\text { (n) }\end{array}$ & $\begin{array}{l}\text { DA }^{\dagger} \\
\text { (n) }\end{array}$ & $\begin{array}{l}\mathrm{SF}^{\dagger} \\
(\mathrm{n})\end{array}$ & $\begin{array}{c}\mathrm{MH}^{\dagger} \\
(\mathrm{n})\end{array}$ & $\begin{array}{l}\mathbf{R D}^{\dagger} \\
\text { (n) }\end{array}$ & $\begin{array}{l}\mathrm{DP}^{\dagger} \\
(\mathrm{n})\end{array}$ & $\begin{array}{l}\mathrm{DR}^{\dagger} \\
(\mathrm{n})\end{array}$ & $\begin{array}{l}\mathrm{CV}^{\dagger} \\
(\mathrm{n})\end{array}$ & $\begin{array}{l}P^{+} \\
(n)\end{array}$ \\
\hline $\begin{array}{l}\text { Assessment of } \\
\text { Disability } \\
\text { Related to } \\
\text { Vision }\end{array}$ & $\begin{array}{l}.496^{*} \\
(91)\end{array}$ & $\begin{array}{l}.453^{*} \\
(91)\end{array}$ & $\begin{array}{l}.152 \\
(91)\end{array}$ & $\begin{array}{l}.419^{*} \\
(91)\end{array}$ & $\begin{array}{l}.308^{*} \\
(91)\end{array}$ & $\begin{array}{c}.429^{*} \\
(91)\end{array}$ & $\begin{array}{c}.499^{*} \\
(91)\end{array}$ & $\begin{array}{l}.415^{\star} \\
(91)\end{array}$ & $\begin{array}{l}.438^{*} \\
(91)\end{array}$ & $\begin{array}{l}.290 \\
(54)\end{array}$ & $\begin{array}{l}.310 \\
(91)\end{array}$ & $\begin{array}{l}.299 \\
(91)\end{array}$ \\
\hline $\begin{array}{l}\text { Reading in } \\
\text { Reduced } \\
\text { Illumination }\end{array}$ & $\begin{array}{l}.163 \\
(91)\end{array}$ & $\begin{array}{l}.058 \\
(91)\end{array}$ & $\begin{array}{l}.224 \\
(91)\end{array}$ & $\begin{array}{l}.108 \\
(91)\end{array}$ & $\begin{array}{l}.053 \\
(91)\end{array}$ & $\begin{array}{l}.130 \\
(91)\end{array}$ & $\begin{array}{l}.231 \\
(91)\end{array}$ & $\begin{array}{l}.111 \\
(91)\end{array}$ & $\begin{array}{l}.188 \\
(91)\end{array}$ & $\begin{array}{l}.243 \\
(54)\end{array}$ & $\begin{array}{l}-.006 \\
(91)\end{array}$ & $\begin{array}{l}.052 \\
(91)\end{array}$ \\
\hline $\begin{array}{l}\text { Facial } \\
\text { Expression } \\
\text { Recognition }\end{array}$ & $\begin{array}{l}.514^{\star} \\
(91)\end{array}$ & $\begin{array}{l}.471^{*} \\
(91)\end{array}$ & $\begin{array}{l}.211 \\
(91)\end{array}$ & $\begin{array}{l}.415^{\star} \\
(91)\end{array}$ & $\begin{array}{l}.383^{*} \\
(91)\end{array}$ & $\begin{array}{c}.418^{*} \\
(91)\end{array}$ & $\begin{array}{l}.501^{*} \\
(91)\end{array}$ & $\begin{array}{l}.418^{*} \\
(91)\end{array}$ & $\begin{array}{l}.326 \\
(91)\end{array}$ & $\begin{array}{l}.273 \\
(54)\end{array}$ & $\begin{array}{l}.415^{*} \\
(91)\end{array}$ & $\begin{array}{l}.331 \\
(91)\end{array}$ \\
\hline $\begin{array}{l}\text { Motion } \\
\text { Detection }\end{array}$ & $\begin{array}{l}.523^{*} \\
(91)\end{array}$ & $\begin{array}{l}.411^{*} \\
(91)\end{array}$ & $\begin{array}{l}.172 \\
(91)\end{array}$ & $\begin{array}{l}.520^{*} \\
(91)\end{array}$ & $\begin{array}{l}.378^{*} \\
(91)\end{array}$ & $\begin{array}{l}.439^{*} \\
(91)\end{array}$ & $\begin{array}{l}.399^{*} \\
(91)\end{array}$ & $\begin{array}{l}.432^{*} \\
(91)\end{array}$ & $\begin{array}{l}.471^{*} \\
(91)\end{array}$ & $\begin{array}{l}.471^{*} \\
(54)\end{array}$ & $\begin{array}{l}.398^{*} \\
(91)\end{array}$ & $\begin{array}{l}.317 \\
(91)\end{array}$ \\
\hline $\begin{array}{l}\text { Recognizing } \\
\text { Street Sings }\end{array}$ & $\begin{array}{l}.412^{*} \\
(91)\end{array}$ & $\begin{array}{l}.461^{*} \\
(91)\end{array}$ & $\begin{array}{l}-.043 \\
(91)\end{array}$ & $\begin{array}{l}.363^{*} \\
(91)\end{array}$ & $\begin{array}{l}.305 \\
(91)\end{array}$ & $\begin{array}{l}.351 \\
(91)\end{array}$ & $\begin{array}{l}.432^{*} \\
(91)\end{array}$ & $\begin{array}{l}.303 \\
(91)\end{array}$ & $\begin{array}{l}.334 \\
(91)\end{array}$ & $\begin{array}{l}.229 \\
(54)\end{array}$ & $\begin{array}{l}.299 \\
(91)\end{array}$ & $\begin{array}{l}.319 \\
(91)\end{array}$ \\
\hline $\begin{array}{l}\text { Locating } \\
\text { Objects }\end{array}$ & $\begin{array}{l}.473^{*} \\
(91)\end{array}$ & $\begin{array}{l}.449^{*} \\
(91)\end{array}$ & $\begin{array}{l}.142 \\
(91)\end{array}$ & $\begin{array}{l}.308 \\
(91)\end{array}$ & $\begin{array}{l}.324 \\
(91)\end{array}$ & $\begin{array}{l}.436^{*} \\
(91)\end{array}$ & $\begin{array}{l}.483^{*} \\
(91)\end{array}$ & $\begin{array}{l}.369^{*} \\
(91)\end{array}$ & $\begin{array}{l}.383^{*} \\
(91)\end{array}$ & $\begin{array}{l}.258 \\
(54)\end{array}$ & $\begin{array}{l}.326 \\
(91)\end{array}$ & $\begin{array}{l}.342 \\
(91)\end{array}$ \\
\hline Ambulation & $\begin{array}{l}.113 \\
(91)\end{array}$ & $\begin{array}{l}.075 \\
(91)\end{array}$ & $\begin{array}{l}.161 \\
(91)\end{array}$ & $\begin{array}{l}.144 \\
(91)\end{array}$ & $\begin{array}{l}.115 \\
(91)\end{array}$ & $\begin{array}{l}.216 \\
(91)\end{array}$ & $\begin{array}{l}.044 \\
(91)\end{array}$ & $\begin{array}{l}.094 \\
(91)\end{array}$ & $\begin{array}{c}-.014 \\
(91)\end{array}$ & $\begin{array}{l}.146 \\
(54)\end{array}$ & $\begin{array}{l}.001 \\
(91)\end{array}$ & $\begin{array}{c}-.031 \\
(91)\end{array}$ \\
\hline $\begin{array}{l}\text { Placing Peg in } \\
\text { Holes }\end{array}$ & $\begin{array}{l}.183 \\
(91)\end{array}$ & $\begin{array}{l}.218 \\
(91)\end{array}$ & $\begin{array}{c}-.086 \\
(91)\end{array}$ & $\begin{array}{l}.229 \\
(91)\end{array}$ & $\begin{array}{l}.124 \\
(91)\end{array}$ & $\begin{array}{l}.198 \\
(91)\end{array}$ & $\begin{array}{l}.217 \\
(91)\end{array}$ & $\begin{array}{l}.173 \\
(91)\end{array}$ & $\begin{array}{l}.200 \\
(91)\end{array}$ & $\begin{array}{l}.044 \\
(54)\end{array}$ & $\begin{array}{l}.066 \\
(91)\end{array}$ & $\begin{array}{l}.116 \\
(91)\end{array}$ \\
\hline $\begin{array}{l}\text { Telephone } \\
\text { Simulation }\end{array}$ & $\begin{array}{l}.459^{*} \\
(91)\end{array}$ & $\begin{array}{l}.420^{*} \\
(91)\end{array}$ & $\begin{array}{l}.243 \\
(91) \\
\end{array}$ & $\begin{array}{l}.377^{*} \\
(91)\end{array}$ & $\begin{array}{l}.291 \\
(91)\end{array}$ & $\begin{array}{l}.390^{*} \\
(91)\end{array}$ & $\begin{array}{l}.408 \\
(91)\end{array}$ & $\begin{array}{l}.354 \\
(91)\end{array}$ & $\begin{array}{l}.382^{*} \\
(91)\end{array}$ & $\begin{array}{l}.208 \\
(54)\end{array}$ & $\begin{array}{l}.346 \\
(91)\end{array}$ & $\begin{array}{l}.314 \\
(91)\end{array}$ \\
\hline $\begin{array}{l}\text { Matching } \\
\text { Socks }\end{array}$ & $\begin{array}{l}, 357 \\
(91)\end{array}$ & $\begin{array}{l}.259 \\
(91)\end{array}$ & $\begin{array}{l}.060 \\
(91)\end{array}$ & $\begin{array}{l}.327 \\
(91)\end{array}$ & $\begin{array}{l}.183 \\
(91)\end{array}$ & $\begin{array}{l}.326 \\
(91)\end{array}$ & $\begin{array}{l}.336 \\
(91)\end{array}$ & $\begin{array}{c}.370^{*} \\
(91)\end{array}$ & $\begin{array}{l}.358 \\
(91)\end{array}$ & $\begin{array}{l}.130 \\
(54)\end{array}$ & $\begin{array}{l}.232 \\
(91)\end{array}$ & $\begin{array}{l}.237 \\
(91)\end{array}$ \\
\hline \multicolumn{13}{|c|}{$\begin{array}{l}{ }^{\dagger} \text { VFQ = VFQ total score; GV = general vision; OP = Ocular Pain; NA = Near Activities; DA = Distance Activities; SF = Social } \\
\text { Functioning; MH = Mental Health; RD = Role Difficulties; DP = Dependency; DR = Driving; CV = Color Vision; PV = Peripheral } \\
\text { Vision }\end{array}$} \\
\hline \multicolumn{10}{|c|}{ Significance levels adjusted for multiple comparisons using the Bonferroni method. } & \multicolumn{2}{|c|}{${ }^{*} p<0.05$} & $p>0.05$ \\
\hline
\end{tabular}




\begin{tabular}{|c|c|c|c|}
\hline Dependent Variables & Independent Variables $(x)=$ beta weight $(95 \% \mathrm{CI})^{\star}$ & Bootstrap $^{\dagger}$ & $\mathbf{n}$ \\
\hline \multirow{2}{*}{$\begin{array}{l}\text { Assessment of } \\
\text { Disability Related to } \\
\text { Vision }\end{array}$} & $\begin{array}{l}\text { Binocular Visual Acuity }=-12.4(-16.4--8.3) \text {, Contrast Sensitivity }=7.6(2.5-12.6) \text {, Worse } \\
\text { Eye Visual Acuity }=-2.4(-4.4--0.3) \text {, Better Eye Mean Deviation }=0.3(0.1-0.5)\end{array}$ & - & 91 \\
\hline & Binocular Visual Acuity = -13.6 (-18.2 - -0.3), Contrast Sensitivity = $7.2(0.4-15.4)$ & + & 91 \\
\hline \multirow{2}{*}{$\begin{array}{l}\text { Reading in Reduced } \\
\text { Illumination }\end{array}$} & Binocular Visual Acuity = -2.6 (-3.9 - -1.3) & - & 91 \\
\hline & Binocular Visual Acuity = - $2.4(-5.2--1.1)$ & + & 91 \\
\hline \multirow{2}{*}{$\begin{array}{l}\text { Facial Expression } \\
\text { Recognition }\end{array}$} & Binocular Visual Acuity = -2.3 (-3.3 - -1.3), Contrast Sensitivity = $1.8(0.5-3.0)$ & - & 91 \\
\hline & Binocular Visual Acuity = -2.4 (-4.2 - - 0.3), Contrast Sensitivity = $1.6(0.006-4.0)$ & + & 91 \\
\hline \multirow{2}{*}{ Motion Detection } & Better Eye Mean Deviation = $0.1(0.02-0.1)$ & - & 91 \\
\hline & Better Eye Mean Deviation = $0.1(0.01-0.1)$ & + & 91 \\
\hline \multirow{2}{*}{$\begin{array}{l}\text { Recognizing Street } \\
\text { Signs }\end{array}$} & Binocular Visual Acuity = -3.2 (-4.1 - -2.4), Better Eye Mean Deviation = $0.1(0.02-0.09)$ & - & 91 \\
\hline & Binocular Visual Acuity = -3.3 (-4.7 - -1.2), Better Eye Mean Deviation $=0.1(0.01-0.1)$ & + & 91 \\
\hline \multirow[t]{2}{*}{ Locating Objects } & $\begin{array}{l}\text { Contrast Sensitivity }=1.3(0.4-2.2) \text {, Binocular Visual Acuity }=-1.1(-1.8--0.4) \text {, Worse Eye } \\
\text { Mean Deviation }=0.05(0.02-0.08)\end{array}$ & - & 91 \\
\hline & Contrast Sensitivity = $1.2(0.5-2.7)$, Worse Eye Mean Deviation $=0.04(0.01-0.11)$ & + & 91 \\
\hline \multirow{2}{*}{ Placing Peg in Holes } & Contrast Sensitivity = $2.0(0.7-3.4)$, Better Eye Visual Acuity $=-1.0(-1.9--0.02)$ & - & 91 \\
\hline & Contrast Sensitivity = $1.8(0.7-4.0)$ & + & 91 \\
\hline \multirow{2}{*}{ Telephone Simulation } & Binocular Visual Acuity = -2.6 (-3.7 - -1.5), Worse Eye Visual Acuity = -0.6 (-1.6 - -0.1) & - & 91 \\
\hline & Binocular Visual Acuity = -2.4 (-5 - - 1.3) & + & 91 \\
\hline \multirow{2}{*}{ Matching Socks } & Better Eye Mean Deviation = $0.1(0.03-0.18)$ & - & 91 \\
\hline & Better Eye Mean Deviation = $0.1(0.01-0.25)$ & + & 91 \\
\hline
\end{tabular}




\section{Table VI: Assessment of Disability Related to Vision Test Description}

1. Reading in reduced illumination

Near vision is checked by obtaining the smallest Jaeger line, then one at a time, 7 sentences, text size corresponding to 2 Jaeger lines above the smallest Jaeger read, are presented. Light illumination is reduced after each sentence is read. The corresponding score is as follows: 1 point, able to read at 200 foot candles (FC), 2 at $150 \mathrm{FC}, 3$ at $100 \mathrm{FC}, 4$ at $50 \mathrm{FC}, 5$ at $25 \mathrm{FC}, 6$ at $10 \mathrm{FC}$ and 7 at $5 \mathrm{FC}$. The highest score is 7 and lowest score is 0 .

\section{Facial expression recognition}

Seven full-face professional, colored photos of varying sizes and facial expressions (angry, sad, happy, or surprised) are presented on a computer screen at a distance of 1/2 meter. The patient receives one point for recognizing the right facial expression. Score ranged from 7 to 0 .

\section{Computerized Motion Detection}

A large black cross against a white background on a computer screen provides a point of fixation. While fixating on the cross, one at a time, 14 balls of different sizes and colors move diagonally across the screen from either the right or the left side at a constant speed. Yellow, red, or blue balls are used. The patient is asked to count the number of moving balls. Each ball seen counts as $1 / 2$ point. Highest score is 7 and lowest score is 0 .

\section{Recognizing street signs}

Seven written word signs ranging from large to small are read at a distance of 4 meters. One character in each sign, was changed from familiar phrases making the word difficult to guess. For example, the top sign reads SUGAR DANE, which is similar to the more familiar sugar cane. The patient is instructed not to guess. One point is given for each sign read correctly. Highest score is 7 and lowest score is 0 .

\section{Locating objects}

Fourteen red and beige boxes of different sizes are scattered around the testing room ( $4 \times 2$ meters). Sample boxes are shown before test started. The patient attempts to locate the boxes while seated. Each box found is worth $1 / 2$ point. Highest score will be 7 and lowest 0 .

\section{Ambulation test}

A 4.5 meter predefined mobility course was designed, with taped horizontal, vertical and diagonal lines and objects made of styrofoam in the path. Several objects were also suspended from the ceiling along the path. Patients were permitted to use a mobility aid (e.g. cane).

The score is based on number of obstacles hit. Each obstacle successfully avoided was awarded $1 / 3$ point. The highest score is 7 and lowest is 0.

\section{Placing a peg into different sized holes}

Seven ( $9 \times 3 \times 3 / 8$ inches) wooden boards were created with 1 hole of varying sizes and location. A wooden stand was created with slots to hold the boards one at time at different angles. The patient is asked to place the peg directly in the hole without touching the board. One point is awarded for successful completion.

\section{Telephone simulation}

Seven calculators of different sizes are used to simulate dialing a telephone. The numbers are randomly rearranged to eliminate memory being used to locate the telephone numbers. The numbers are printed from different font sizes and presented to patients from largest to smallest. The patient is asked to press seven different numbers on each of the various sized calculators. The patient must find all seven numbers to receive a point for that calculator. For each number correctly "dialed", the patient receives one point. The highest score is 7 and lowest 0.

\section{Matching socks}

Seven differently patterned, dark-colored socks were hung on a board with a grey background. The patients are not permitted to touch the socks hanging on the wall. The patient sits in front of a table 1 
meter wide so as to be 1 meter from the socks. On the table is a group of 10 socks, 7 of which are the pairs for the hanging socks. The patient is asked to match the socks on the table with those on the board. One point is awarded for each correctly matched sock. The highest score is 7 and lowest 0 . 


\section{References}

1. Yamaoka K, Shigehisa T, Ogoshi K, et al. Health-related quality of life varies with personality types: a comparison among cancer patients, non-cancer patients and healthy individuals in a Japanese population. Qual Life Res 1998;7:535-44.

2. Kempen GIJM, Jelicic M, Ormel J. Personality, Chronic Medical Comorbidity, and Health-Related Quality of Life Among Older Persons. Health Psychol 1997;16:539-546.

3. Owsley C, McGwin G, Jr. Depression and the 25-item National Eye Institute Visual Function Questionnaire in older adults. Ophthalmology 2004;111:2259-64.

4. Feldman PJ, Cohen S, Doyle WJ, Skoner DP, Gwaltney JMJ. The Impact of Personality on the Reporting of Unfounded Symptoms and Illness. J Pers Soc Psychol 1999;77:370-378.

5. Deary IJ, Scott S, Wilson JA. Neuroticism, Alexithymia, and Medically Unexplained Symptoms. Pers Individ Dif 1997;22:551-564.

6. Massof RW, Fletcher DC. Evaluation of the NEI visual functioning questionnaire as an interval measure of visual ability in low vision. Vision Res 2001;41:397-413.

7. Ebert EM, Fine AM, Markowitz J, Maguire MG, Starr JS, Fine SL. Functional vision in patients with neovascular maculopathy and poor visual acuity. Arch Ophthalmol 1986;104:1009-12.

8. Turco PD, Connolly J, McCabe P, Glynn RJ. Assessment of functional vision performance: a new test for low vision patients. Ophthalmic Epidemiol 1994;1:15-25.

9. West SK, Munoz B, Rubin GS, et al. Function and visual impairment in a population-based study of older adults. The SEE project. Salisbury Eye Evaluation. Invest Ophthalmol Vis Sci 1997;38:72-82.

10. McCabe P, Nason F, Demers Turco P, Friedman D, Seddon JM. Evaluating the effectiveness of a vision rehabilitation intervention using an objective and subjective measure of functional performance. Ophthalmic Epidemiol 2000;7:259-70.

11. Haymes SA, Johnston AW, Heyes AD. Preliminary investigation of the responsiveness of the Melbourne Low Vision ADL index to low-vision rehabilitation. Optom Vis Sci 2001;78:373-80.

12. Chylack LT, Jr., Leske MC, McCarthy D, Khu P, Kashiwagi T, Sperduto R. Lens opacities classification system II (LOCS II). Arch Ophthalmol 1989;107:991-7.

13. Optic nerve decompression surgery for nonarteritic anterior ischemic optic neuropathy (NAION) is not effective and may be harmful. The Ischemic Optic Neuropathy Decompression Trial Research Group. Jama 1995;273:625-32.

14. Altangerel U, Spaeth GL, Steinmann WC. Assessment of function related to vision (AFREV). Ophthalmic Epidemiol 2006;13:67-80.

15. Lorenzana L, Lankaranian D, Dugar J, et al. A new method of assessing ability to perform activities of daily living: design, methods and baseline data. Ophthalmic Epidemiol 2009;16:107-14.

16. Warrian KJ, Lorenzana LL, Lankaranian D, Dugar J, Wizov SS, Spaeth GL. Assessing agerelated macular degeneration with the ADREV performance-based measure. Retina 2009;29:80-90.

17. Mangione CM, Berry S, Spritzer K, et al. Identifying the content area for the 51-item National Eye Institute Visual Function Questionnaire: results from focus groups with visually impaired persons. Arch Ophthalmol 1998;116:227-33.

18. Mangione CM, Lee PP, Pitts J, Gutierrez P, Berry S, Hays RD. Psychometric properties of the National Eye Institute Visual Function Questionnaire (NEI-VFQ). NEI-VFQ Field Test Investigators. Arch Ophthalmol 1998;116:1496-504.

19. Mangione CM, Lee PP, Gutierrez PR, Spritzer K, Berry S, Hays RD. Development of the 25-item National Eye Institute Visual Function Questionnaire. Arch Ophthalmol 2001;119:1050-8.

20. Klein R, Moss SE, Klein BE, Gutierrez P, Mangione CM. The NEI-VFQ-25 in people with longterm type 1 diabetes mellitus: the Wisconsin Epidemiologic Study of Diabetic Retinopathy. Arch Ophthalmol 2001;119:733-40.

21. Tranos PG, Topouzis F, Stangos NT, et al. Effect of laser photocoagulation treatment for diabetic macular oedema on patient's vision-related quality of life. Curr Eye Res 2004;29:41-9.

22. Cusick M, SanGiovanni JP, Chew EY, et al. Central visual function and the NEI-VFQ-25 near and distance activities subscale scores in people with type 1 and 2 diabetes. Am $\mathrm{J}$ Ophthalmol 2005;139:1042-50.

23. Glantz SA. Primer of Biostatistics, 5 ed. Chicago, IL: McGraw-Hill, 2002.

24. Huber PJ. Robust Statistics. New York, NY: John Wiley \& Sons, 1981. 
25. Cohen J. Statistical Power Analysis for the Behavioral Sciences, 2 ed. Hillsdale, NJ: Lawrence Erlbaum Associates, 1988.

26. Rousseeuw PJ, Leroy AM. Robust Regression and Outlier Detection. New York, NY: John Wiley \& Sons, 1987.

27. Huber M, Rousseeuw PJ. Robust regression with both continuous and binary regressors. Journal of Statistical Planning and Inference 1997;57:153-163.

28. Harlow LL. The essence of multivariate thinking. Mahwah, NJ: Lawrence Erlbaum Associates, 2005.

29. Marascuilo LA, Levin JR. Multivariate statistics in the social sciences: A research guide. Monterey, CA: Brooks/ Cole Publishing Company, 1983.

30. Efron B. Bootstrap methods: another look at the jackknife. Ann Stat 1979;7:1-26.

31. Shorack GR. Bootstrapping Robust Regression. Communications in Statistics - Theory and Methods 1982;11:961-972.

32. Thompson B. The use of statistical significance tests in research: Bootstrap and other alternatives. J Exp Educ 1993;61:361-377.

33. Bland JM, Altman DG. Multiple significance tests: the Bonferroni method. Bmj 1995;310:170.

34. Faul F, Erdfelder E, Lang AG, Buchner A. G*Power 3: A flexible statistical power analysis program for the social, behavioral and biomedical sciences. Behav Res Meth 2007;39:175-191.

35. Paz SH, Globe DR, Wu J, Azen SP, Varma R. Relationship between self-reported depression and self-reported visual function in Latinos. Arch Ophthalmol 2003;121:1021-7.

36. Haymes SA, Johnston AW, Heyes AD. A weighted version of the Melbourne Low-Vision ADL Index: a measure of disability impact. Optom Vis Sci 2001;78:565-79.

37. Wall M, Jennisch CS. Random dot motion stimuli are more sensitive than light stimuli for detection of visual field loss in ocular hypertension patients. Optom Vis Sci 1999;76:550-7. 